\title{
Examination of Reading Texts Taking Place in 3-8th Grades' Science Textbooks
}

\author{
İlkay Aşkin Tekkol*, Hafife Bozdemir, Eyüp Akman
}

Faculty of Education, Kastamonu University, Turkey

Copyright $\bigcirc 2018$ by authors, all rights reserved. Authors agree that this article remains permanently open access under the terms of the Creative Commons Attribution License 4.0 International License

\begin{abstract}
In this research, reading texts in science textbooks of 3-8th grades were analyzed in terms of some variables. As these texts were analyzed, the units where these texts took place in the textbooks, contents of the texts, supporting the texts by some visual materials, specifying sources and naming the texts were taken into consideration. Moreover, the texts were analyzed in terms of type, source and visual elements. According to the research results, it was observed that all of the texts used in 3-8th grades' science textbooks were informative texts. Texts did not show equal distribution according to grades and units. Nearly half of the texts were supported by visual elements. Small number of texts pointed to references. However, these references did not have adequate variety.
\end{abstract}

Keywords Science, Science Textbooks, Reading Texts

\section{Introduction}

The period in which children begin to school is a time when they are faced with a new social environment and are beginning to acquire new knowledge. This period can be considered as a different period for children. The children who are in the process of concrete operations cognitively when they started school, go through a period of abstract operations as their age progresses. Although this transition period is related to age, the children's learning is noticed to be affected majorly by their interaction with their teachers and friends. Vygotsky [1] states that higher order cognitive learning is directly related to the interaction and socialization of individuals by their environment. In the first years of elementary school, the child who is in the period of concrete operations as Piaget [2] mentions, learns via concrete materials and enriches the schemes. In this period, students learn more easily the information they have in their surroundings and can connect with their daily lives [2]. In this sense, science is emerging as an area where children can start to learn during concrete operations and expand their schemes and create new schemes, where they can gain higher order cognitive skills during abstract operations. For example children initially have the notion that "All microorganisms are harmful." Then, they enrich their scheme "Not all microorganisms are harmful, some of them are helpful." Science is regarded as an important part of human cultures and it contributes to the development of people's lives through basic ways [3]. Since science has an important place in the economic development of countries, it has been given special importance to science education in order to educate individuals who can produce information and technology [4]. It is very important that science-related teaching activities are matched to a child age, development level and abilities [5]. In this context, science course curricula have changed and developed in our country over the years. The course has taken names such as "Natural Science", "Science and Nature Information", "Science and Technology" and "Science" [6] and although it was started to be given commenced previously from the fourth year of education, later it has started to be carried out under the name of "Science Course" from the beginning of the third class. This curriculum has undergone changes in 2017. In 2018, it was updated once again. In this context, textbooks have also been updated. Currently, textbooks are organized according to 2013 and 2017 programs. Textbooks are a tool for presenting the content of the curriculum to students [7]. According to Göçer [8], textbooks are among the important tools that enable the teachers and students to carry out their activities in the teaching-learning process in an orderly manner. Bakar, Keleş and Koçakoğlu [9] emphasize that success in science education depends on the co-ordination and use of teachers, students and educational technologies as well as content, educational design and physical characteristics of textbooks. When the currently used science textbooks are examined, it is seen that there are key concepts related to the unit, topics to be learned, information about the topics, questions and activities in accordance with the units. Also there are reading texts in every grade (3-8th grade) textbooks and texts have been naming differently. These texts contain information that is 
thought to attract students' attention. The aim of this research is to examine the reading texts in the science textbooks (3-8th grade) from various angles. It can be thought that this study contributes the text book authors to pay attention (distribution of units, naming in terms of grade, text topics, supported by visual materials, references) to preparing reading text. In response to this objective, it was examined;

- reading texts used in 3-8th grades' science textbooks distribution of units,

- reading texts used in 3-8th grades' science textbooks naming in terms of grade,

- reading texts used in 3-8th grades' science textbooks of topics,

- reading texts used in 3-8th grades' science textbooks supported by visual materials,

- reading texts used in 3-8th grades' science textbooks references.

\section{Materials and Methods}

In this research, document review method was used which is one of qualitative research methods. The document review includes an analysis of written materials containing information about the cases or phenomena targeted to be investigated [10]. Within the scope of the study the reading texts in 3-8th grades' science textbooks in Turkey have been examined in terms of various variables. A total of 62 reading texts were included in the study. Reading texts example is took part in Appendix 1.

\subsection{Data Collection}

A classification form was prepared by the researchers to examine the texts covered by the research. The categories included in the form are;

- The units where reading texts are located,

- The topics related with the reading texts,

- Naming of reading texts according to class levels,

- Sources of readings

- The issue of reading texts whether they are supported by visual materials or not

In the study, the texts were examined and integrated separately by the researchers according to the titles identified.

\subsection{Analysis of Data}

In the analysis of the data, descriptive analysis was used which is one of the qualitative data analysis techniques. The reading parts in science textbooks are examined according to the determined categories and their frequencies are calculated and tabulated.

\section{Results}

It has been determined that all of the texts included in science textbooks are in the form of informative texts. It is seen that there are also biographies among them. In particular, it was determined that all the texts given in the title of "Heroes of Science" at the 5th grade are in the biography type. The distribution of reading texts in science textbooks according to their contents is presented in Table 1.

According to Table 1, it is seen that there are 19 reading texts in grade 3, 9 at grade 4,10 at grade 5, 4 at grade 6 , 13 at grade 7 , and 7 at grade 8 levels. When the distribution of reading texts in terms of units at 3 rd grade level is examined, it is found that most of the reading texts are in "Our Five Senses" unit $(\mathrm{f}=6)$, and reading texts take place in every unit. At the fourth grade level it was determined that reading texts were found in "Getting to Know Matter" ( $\mathrm{f}=5)$, unit at most. Reading texts have not been found in the "Lighting and Sound Technologies from Past to Present" and "Simple Electric Circuits" units. There are more reading texts $(\mathrm{f}=3)$ in the "Force Measurement" unit at the 5th grade than the other units. Reading texts are not given place in the "Matter and Transmission" unit. At 6th grade level, there are reading texts in the "Light and Sound" ( $\mathrm{f}=2)$, "Granular Structure of Matter" ( $\mathrm{f}=1)$ and "The Systems in our Body" ( $\mathrm{f}=1)$ units and there are no reading texts in other units. Reading texts at 7 th grade level seem to be distributed evenly across all units. Finally, it is observed that reading texts at the 8th grade level take place in the "Structure and Features of the Matter" ( $\mathrm{f}=5$ ) unit at most and there are no reading texts in "Human Reproduction, Growth and Development", "Simple Machines", "Living Creatures and Energy Associations", "States of Matter and Heat" and "Earthquake and Weather Events" units. The distribution of reading texts by class levels is shown in the figure on the side (Figure 1).

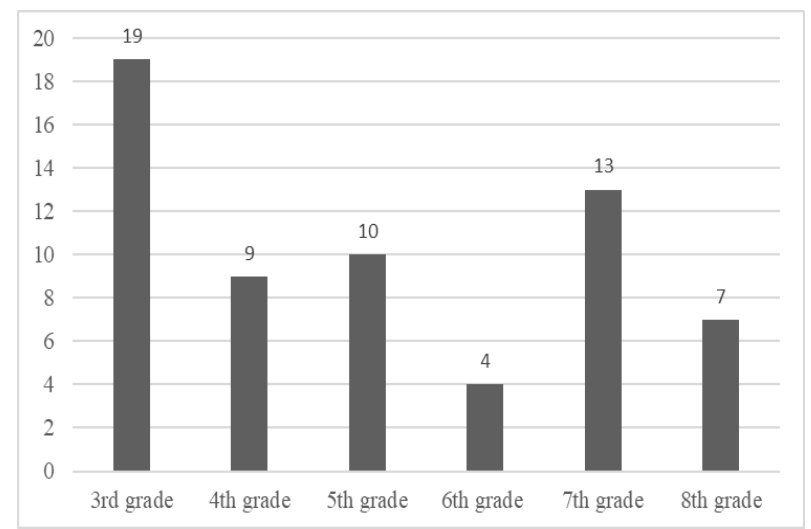

Figure 1. Distribution of Reading Texts by Grades 
Table 1. Distribution of Reading Texts in Units in Science Textbooks

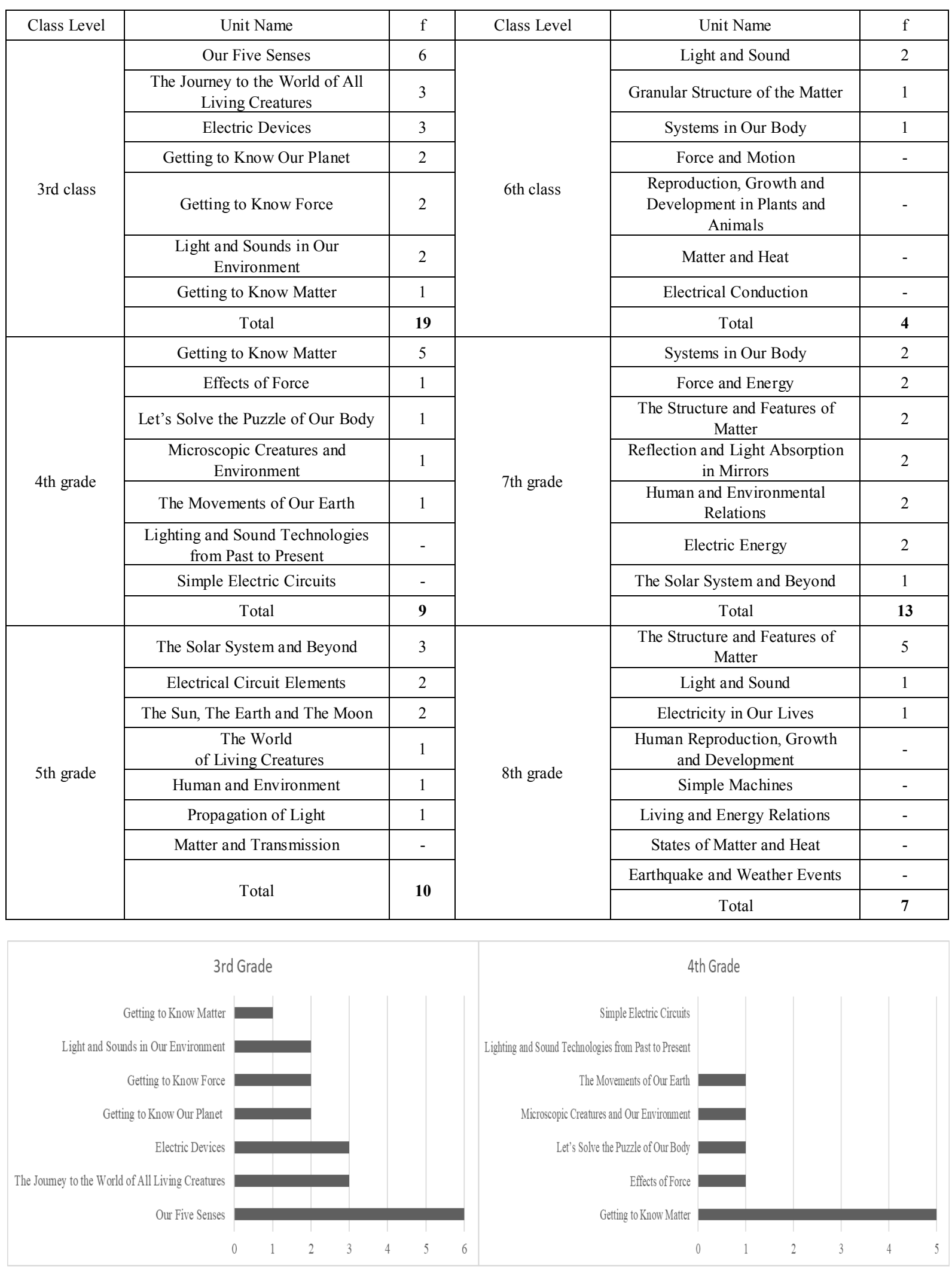




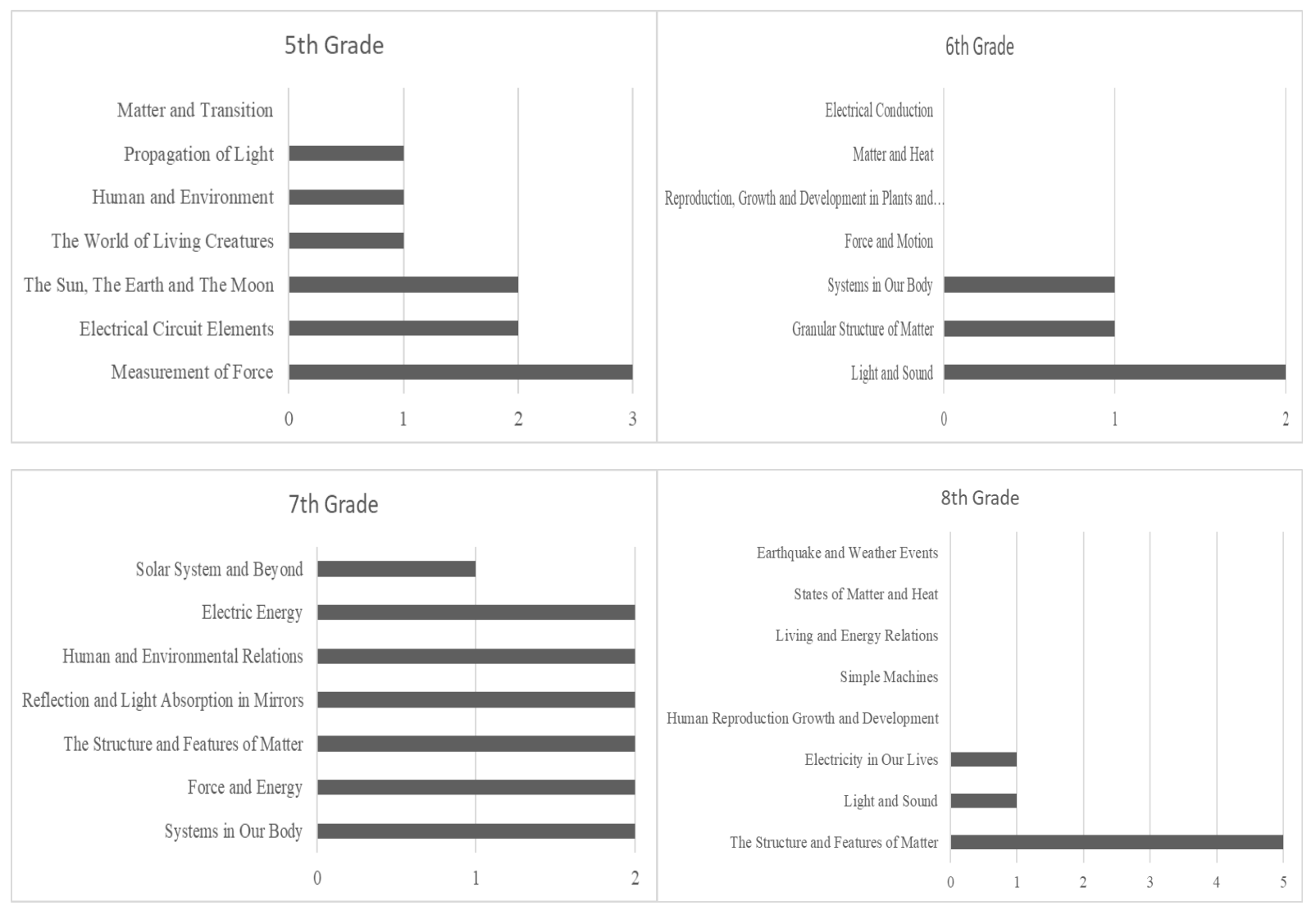

Figure 2. Distribution of Reading Texts by Units

When Figure 1 is examined, it is seen that the maximum number of reading texts are at the level of the 3 rd grade, and the minimum number of texts are at the level of the 6th grade. It is understood that the graphical reading texts do not show a balanced distribution according to the grades. The graph of distribution of reading texts according to the units at each grade is given in Figure 2.

When the chart is examined, it is seen that reading texts in the units are not balanced, while some units have more than one reading text, others do not have reading texts. The table for naming reading texts by class level is given below (Table 2).

Table 2. Naming Reading Texts in Science Textbooks According to Grade

\begin{tabular}{|c|c|}
\hline Grade Level & Name \\
\hline 3rd grade & Do you know? \\
\hline 4th grade & To Enthusiasts \\
\hline 5th grade & Heroes of Science \\
\hline 6th grade & Science, Technology, Society and Environment \\
\hline \multirow{2}{*}{ 7th grade } & Knowledge Box \\
\cline { 2 - 3 } & Reading Part \\
\hline \multirow{2}{*}{ 8th grade } & Reading Text \\
\cline { 2 - 3 } & Do you know these? \\
\hline
\end{tabular}

According to Table 2, it is seen that reading texts are named as; at 3rd grade level "Do you know?"; at 4th grade level "To Enthusiasts"; at 5th grade level "Heroes of Science"; at 6th grade level "Science, Technology, Society and Environment"; at 7th grade level "Knowledge Box" and "Reading Part"; at 8th grade level "Reading Text" and "Do You Know These?". Below is a table of contents of reading texts that take place in science textbooks (Table 3).

When Table 2 is examined, it is seen that the reading texts of the "Our Five Senses" unit at the 3rd grade level are related to the unit, including the visual, auditory, tasting, and touching. In the "Journey to the World" unit there are environmentally-oriented texts and in the "Electric Devices" unit there are texts that include battery/waste batteries and emergency assistance numbers. In the "Getting to Know Our Planet" unit, it is determined that there are texts about the formation and layers of the Earth. In the "Getting to Know Force" unit, texts containing the movement of sunflowers and a cross section of Naim Suleymanoglu's life were given. It is seen that in the "Light and Sounds in the Environment" unit there are texts describing the formation of the rainbow and the method of treating the mental patients of İbn-i Sina with music. There is also an informative text on the diamond in the "Getting to Know Matter" unit. It is determined that at the class 4th grade level, there are texts containing skunk and the liquid it spreads, mass of small grained solids, volume of smoothly shaped geometric 
objects, function of thermos, magnets and separation of waste. Flexibility in the "Effects of Force" unit; objects that go down to the windpipe in the "Let's Solve the Puzzle of our Body" unit; the period of disintegration of plastic and glass in the "Microscopic Living and Environment" unit; in the "Movements of Our Earth" unit, there are reading texts about the break of dawn/dayspring. In the "Force Measurement" unit, Isaac Newton, Hezarfen Ahmet Çelebi, Vecihi Hürkuş; in the "Electrical Circuit Elements" unit, Nikola Tesla and Thomas Alva Edison; in the "The Sun, The Earth and The Moon" unit, Galileo Galilei, Ali Kuşcu; in the "The World of Living Creatures" unit Aristotales/Carolus Linneaus; in the "People and the Environment" unit Rachel Louise Carson; in the "Propagation of Light" unit there are reading texts at 5th grade level which include scientists and their study fields, such as "İbn-i Heysem". At the 6th grade level, it's seen that in the "Light and Sound" unit there are reading texts themed the invention of periscope, sonar, ultrasonic and radar devices; in "Granular Structure of Matter" unit submarines; in the "Systems in our Body" unit the discovery of X-rays and Wilhelm Condrad X-ray. At the 7th grade level in the "Systems in our Body" unit, there are reading texts about the right and left hemispheres of the brain and diabetes. In the "Force and Energy" unit, there are reading texts including equal-arm scale, the comparison of mass and weight with Earth and other planets. In the "Structure and Features of the Matter" unit, it has been determined that there are texts that themed the number of protons of the atoms and the ionic charges and the proton numbers of the elements. In the "Mirror Reflection and Light Absorption" unit, there are texts on development of mirrors up to today and reflection of light. In the "Human and Environment Relations" unit, it is seen that there are reading texts describing corals and deserts. In the "Electric Energy" unit they give place to reading text themed energy sources and filament lamps, fluorescent lamps and energy saving lamps; in the "Solar System and Beyond" unit there are texts describing Pluto. At the 8th grade level publication of the periodic table and Dimitri Ivanovich Mendeleyev in the "Structure and Features of the Matter" unit; Discovery of Lecoq de Boisbaudran and discovery of gallium; number of compounds; the duties of chemist and chemistry engineers; information for some elements; in the "Light and Sound" unit forest fires and education of the people in the prevention; in the "Electricity in our lives" unit, it has been determined that there are reading texts including the discovery of electricity.

Information on the support of visual materials in science textbooks and the sources of these texts are presented in Table 4.

According to the Table 4 it has been determined that, 13 out of 19 reading texts at the 3rd grade level; 3 out of 9 reading texts at the 4 th grade level; all 10 reading texts at 5 th grade level; all 4 reading texts at 6 th grade level; 3 out of 13 reading texts at the 7 th grade level; 1 out of the 7 reading texts at the 8 th grade level is supported visually. When examining the status of references, it's seen that source of 4 reading texts are mentioned at the 6th grade level; 13 reading texts at the 7 th grade level; 3 reading texts at the 8th grade level. It appears that the sources of the texts in the other grade levels are not mentioned. 
Table 3. Contents of Reading Texts in Science Textbooks

\begin{tabular}{|c|c|c|}
\hline Class Level & Unit Name & Content \\
\hline \multirow{7}{*}{$3^{\text {rd }}$ grade } & Our Five Senses & $\begin{array}{l}\text { Invention of Eyewear/ Salvino d'Armate, Production of Eyewear Handle/ Edward } \\
\text { Scarlett, Invention of Stethoscope/Rene Laennec, Invention of Bionic ear/ Graeme } \\
\text { Clark, , Sensation of the taste in Fish, Sensitivity of the Parts in the Skin, Invention of } \\
\text { the sun cream / Evgene Schueller }\end{array}$ \\
\hline & Journey to the World of Living & Recycling, Ozone layer, Amount of renewable energy source \\
\hline & Electric Devices & $\begin{array}{c}\text { Allessandro Volta / Invention of battery, TAP Association of Mobile Battery } \\
\text { Manufacturers and Importers, Emergency help and rescue, electrical breakdown, fire } \\
\text { alarm numbers }\end{array}$ \\
\hline & Getting to know our planet & The formation of the Earth, Layers of the Earth \\
\hline & Getting to Know Force & Movements of Sunflowers, Naim Süleymanoğlu \\
\hline & $\begin{array}{c}\text { The Light and Sounds in the } \\
\text { Environment }\end{array}$ & The formation of the rainbow, Ibn-i Sina / The treatment of mental illness with music \\
\hline & Getting to know Matter & Diamond \\
\hline \multirow{5}{*}{$4^{\text {th }}$ Grade } & Getting to know Matter & $\begin{array}{l}\text { Skunk and Its Liquid, Mass of Small Grain Solids, Volume of Properly Shaped } \\
\text { Geometrical Objects, Thermos Magnets and Parsing of Wastes }\end{array}$ \\
\hline & Effects of Force & Limit of elasticity, arc \\
\hline & $\begin{array}{l}\text { Let's Solve the Puzzle of Our } \\
\text { Body }\end{array}$ & The speed of the piece that goes down to the windpipe \\
\hline & $\begin{array}{c}\text { Microscopic Living and the } \\
\text { Environment }\end{array}$ & Plastic and glass disintegration period in the nature \\
\hline & The Movements of Our Earth & Dayspring and Dawn break \\
\hline \multirow{6}{*}{$5^{\text {th }}$ Grade } & Force Measurement & Isaac Newton, Hezarfen Ahmet Çelebi, Vecihi Hürkuş \\
\hline & Electrical Circuit Components & Nikola Tesla, Thomas Alva Edison \\
\hline & $\begin{array}{l}\text { The Sun, The Earth and the } \\
\text { Moon }\end{array}$ & Galileo Galilei, Ali Kuşçu \\
\hline & World of Creatures & Aristotales/Carolus Linneaus \\
\hline & People \& Environment & Rachel Louise Carson \\
\hline & Propagation of light & İbn-i Heysem \\
\hline \multirow{3}{*}{$6^{\text {th }}$ Grade } & Light and Sound & Invention of Periscope, Sonar, Ultrasonic and Radar devices \\
\hline & Ultrasonic and Radar devices & Submarines \\
\hline & Systems in our body & Exploration of X-rays / Wilhelm Condrad X-ray \\
\hline \multirow{7}{*}{$7^{\text {th }}$ Grade } & Systems in our body & Right and left hemispheres of the brain, diabetes \\
\hline & Force and Energy & $\begin{array}{l}\begin{array}{l}\text { Equal handled scales in Egyptian excavations, Mass and weight comparison on Earth } \\
\text { and other planets }\end{array} \\
\end{array}$ \\
\hline & $\begin{array}{l}\text { Structure and Features of } \\
\text { Matter }\end{array}$ & Proton numbers and ionic charges of atoms, Proton numbers of elements \\
\hline & $\begin{array}{c}\text { Reflection and Light } \\
\text { Absorption in the Mirrors }\end{array}$ & Mirrors from the past to the present, Reflection of light \\
\hline & $\begin{array}{l}\text { Human and Environment } \\
\text { Relations }\end{array}$ & Corals, Deserts \\
\hline & Electric Energy & Energy sources, filament lamps, fluorescent lamps, power saving lamps \\
\hline & Solar System and Beyond & Pluto \\
\hline \multirow{3}{*}{ 8th Grade } & $\begin{array}{l}\text { Structure and Features of } \\
\text { Matter }\end{array}$ & $\begin{array}{l}\text { Dimitri Ivanovich Mendeleev / Periodic table, Gallium / Lecoq de Boisbaudran, } \\
\text { Number of compounds, Chemist, Chemical engineer, Information for some elements }\end{array}$ \\
\hline & Light and sound & People's education on forest fires \\
\hline & Electricity in Our Life & Discovery of Electricity \\
\hline
\end{tabular}


Table 4. Supporting Visual Materials of Reading Texts in Science Textbooks and Indication of References

\begin{tabular}{|c|c|c|c|c|}
\hline Grade & Visual & $f$ & Resource & $\mathrm{f}$ \\
\hline \multirow{2}{*}{$\begin{array}{c}\text { 3rd } \\
\text { grade }\end{array}$} & Yes & 13 & Yes & - \\
\hline & No & 6 & No & 19 \\
\hline \multirow{2}{*}{$\begin{array}{c}\text { 4th } \\
\text { grade }\end{array}$} & Yes & 3 & Yes & - \\
\hline & No & 6 & No & 9 \\
\hline \multirow{2}{*}{$\begin{array}{c}5 \text { th } \\
\text { grade }\end{array}$} & Yes & 10 & Yes & - \\
\hline & No & - & No & 10 \\
\hline \multirow{3}{*}{$\begin{array}{l}\text { 6th } \\
\text { grade }\end{array}$} & \multirow[b]{2}{*}{ Yes } & \multirow[b]{2}{*}{4} & \multirow[b]{2}{*}{ Yes } & 4 \\
\hline & & & & $\begin{array}{l}\text { TUBITAK, Bilim Çocuk, December 2002, Issue } 60 \\
\text { TÜBİTAK, Bilim Çocuk, Issue 127, } 2008 \text { www.biltek.tubitak.gov.tr./ } \\
\text { tekno_tezgah/teknoyazi/subat2007.pdf } \\
\text { The Mysteries and the Wonders of Science TUBITAK Publications }\end{array}$ \\
\hline & No & - & No & - \\
\hline \multirow{3}{*}{$\begin{array}{c}\text { 7th } \\
\text { grade }\end{array}$} & \multirow[b]{2}{*}{ Yes } & \multirow[b]{2}{*}{3} & \multirow[b]{2}{*}{ Yes } & 13 \\
\hline & & & & $\begin{array}{c}\text { TÜBITAK Bilim Çocuk Dergisi January } 1999 \text { issue } \\
\text { http:www.hurriyet.com.tr/saglik /899737 } \\
\text { http://www.kulturvarliklari.gov.tr/ } \\
\text { sempozyum_pdf/kazilar/05_kazi.pdf } \\
\text { TÜBITAK Bilim Çocuk Dergisi Kasım } 1998 \text { issue } \\
\text { TUBITAK Bilim Çocuk Dergisi February } 1999 \text { issue } \\
\text { TUBITAK Bilim Çocuk Dergisi February } 1999 \text { issue } \\
\text { TUBITAK Science Children's Journal October 1999 issue } \\
\text { Bilim Çocuk Çocuk Dergisi Number of October 1999-June } 2005 \\
\text { TÜBİTAK Bilim Çocuk Dergisi July } 2004 \text { issue } \\
\text { Bilim Çocuk Çocuk Dergisi The number of July } 2002 \\
\text { TUBITAK Bilim Çocuk Dergisi February } 2005 \text { issue } \\
\text { http://www.enerji.gov.tr/File/? path = ROOT\% 2F1\% } \\
\text { 2FDocuments\% 2FBelge\% 2FKVAG_RAporu } \\
\text { TÜBITAK Bilim Çocuk Dergisi September 2006 issue }\end{array}$ \\
\hline & No & 10 & No & - \\
\hline \multirow{3}{*}{$\begin{array}{l}\text { 8th } \\
\text { grade }\end{array}$} & \multirow[b]{2}{*}{ Yes } & \multirow[b]{2}{*}{1} & \multirow[b]{2}{*}{ Yes } & 3 \\
\hline & & & & $\begin{array}{l}\text { www.science.kids.co.nz } \\
\text { www.ogm.gov.tr } \\
\text { www.ogm.gov.tr }\end{array}$ \\
\hline & No & 6 & No & 4 \\
\hline
\end{tabular}

\section{Conclusions}

In this study, 3-8th grades reading texts in science textbooks were examined according to units, naming by units, grades, contents, if they are visually supported or not and their textual sources. In the textbooks; at 3rd grade level there are 19; at the 4th grade level 9; at the 5th grade level 10; at the 6th grade level 4; at the 7th grade level 13 and at the 8th grade level 7; a total of 62 texts, were analyzed within the scope of the research. As a result of the research, it was determined that the maximum number of reading texts is in the third grade and the minimum number of reading texts is in the sixth grade. It is seen that the texts do not show a balanced distribution in terms of grades. The purpose of these texts mentioned in the textbooks is to present important information about the topic by attracting the students' attention [11]. When the curriculum of science course is examined, it is seen that it includes the aim "to raise interest and curiosity and to develop attitudes related to events that take place in the nature and in the vicinity" [12]. When the reading texts in the textbooks are handled for this purpose, it can be thought that the higher number of texts may be more attracting source for the students. For this reason, the number of reading texts is important. Thus, reading texts can be used as a tool for students to achieve this aim. When the distribution of reading texts according to the units is examined, it is seen that the number of texts is higher in some units, less in some, and none in some units. These reading texts can be interested in these subjects and concepts by presenting subjects and concepts related to each unit. When studies on the examination of the textbooks are examined, it is stated that reading texts, cartoons, etc. which will attract the attention of the students are not included at the competence level [13]. It has been determined that the texts in the textbooks are all informative texts and only in the biography type, especially the reading texts at the 5th grade are all in the biography type. When the curriculum of the Turkish course is examined, it is emphasized that the necessity of 
including different kinds of texts is emphasized and it is stated that biographies can be given from the 7 th grade [14]. In this respect, it can be said that the reading texts which are in the 5th grade science textbooks and in the biography type are above the levels of the students. Besides, the process of creation of scientific knowledge by scientists and the place of scientists in this process are among the aims of the program. Therefore, it can be said that these texts are suitable for this purpose of the curriculum. Reading texts at the 3 rd grade are named as "Do you know?"; 4th grade "To Enthusiasts"; 5th grade "Heroes of Science"; 6th grade "Science, Technology, Society and Environment"; 7th grade "Knowledge Box" and "Reading Part"; 8th grade "Reading Text" and "Do You Know These?" It can be thought that reading texts at the 5th grade may limit the students because they cover only the lives of scientists and they do not include any other information. It was also found that only one of the reading texts was taken from the newspaper (Class 7). In the study of Kavak, Tufan and Demirelli [15] investigating the relationship between newspaper news and science-technology, it was determined that the most frequently mentioned dimension of science and technology literacy in news and commentaries in newspapers is science-technology-society-environment relations $(60,9 \%)$. In science textbooks, at the 6th grade level there are only four reading texts with the name "Science-Technology-Society and Environment" and none of them were taken from the newspapers. It has been determined that the contents of the reading texts in the text books are related to the units they are in. Nearly half of the reading texts are not supported by visuals. Especially supporting the texts at the elementary level with visuals makes it easier for students to understand what they read [16]. When reading texts in 3rd and 4th grade textbooks are examined, it is seen that approximately half of the texts are not supported visually. When the studies in the field of the book review are examined, it is seen that the images in the textbooks are not in sufficient level $[13,17$, $18,19]$. According to Idıng [20], visual support of texts provides effective learning and enhances remembrance. According to this, it can be stated that the support of the reading texts visually is a necessity. As a result of examining the texts of science textbooks in terms of their source representation, it was determined that only one third of the texts are supported by sources and these sources are mainly TUBITAK publications. It is seen that only one text is taken from the newspaper and the other texts are taken from the web sites. The importance of accessing information from different sources in curricula is emphasized and the concept of media literacy is emphasized [14]. In this case, it can be said that reading texts are derived from limited sources and that they are missing in using different sources emphasized in curricula.

According to the results of the research, it can be suggested to increase the number of reading texts in science textbooks. These texts may have positive effects on students' learning by attracting interest from the students. Besides, it can be suggested that the texts can be in different genres and taken from different sources. Thus, students can contribute to more effective learning by seeing different types of texts in the teaching-learning process and using different sources. It is also important to point out the sources of the reading texts. At this point, students can deepen their knowledge about the subject by going to the sources they are interested in. Finally, the process of making sense of the students can be contributed by supporting the reading texts visually. Thus, students can make more concrete and meaningful learning.

\section{Appendix 1}

\section{Example of Reading Text $\left(5^{\text {th }}\right.$ Grade)}

Galileo Galilei (1564-1642)

He invented telescope and observed the sunspot on the paper with it. He realized the sunspot movement to the same direction with periodically observations. Thus, he precipitated "Sun rotates on its own axis." Researches after Galleo have proved Sun rotates clockwise on its own axis.

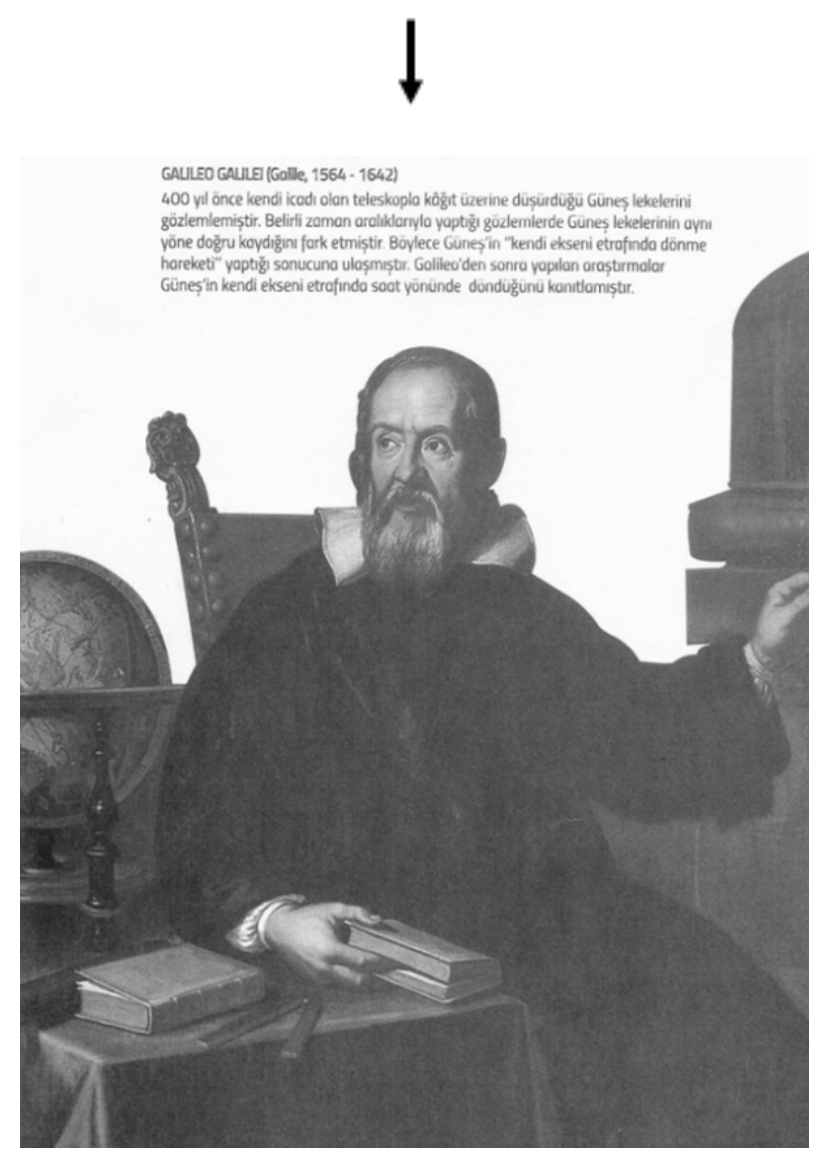




\section{REFERENCES}

[1] Vygotsky, L. Interaction between learning and development. Mind and Society. Cambridge: Harvard University Press, 1978.

[2] Piaget, J. The Growth of Logical Thinking Childhood to Adolescence. USA: Basic Book, Inc, 1958

[3] National Research Council. A Framework for K-12 Science Education. Washington: The National Academic Press, 2012.

[4] Coştu, B., Ayas, A., Çalık, M., Ünal, S. \& Karataş, F. Ö. Determining preservice science teachers' competences in preparing solutions and in use of laboratory tools. Hacettepe University Journal of Education, 28, 65-72, 2005.

[5] Ward, H. Using Their Brains in Science. London: Sage Publication, 2007.

[6] Başar, T. \& Yağc1, E. Evaluation of the curriculum of elementary school third grade science course. EURASIA Journal of Mathematics Science and Technology Education, 13(8), 4609-4633, 2017.

[7] Gülersoy, A. E. The examining of the social studies textbooks in terms of some features in the research of the ideal textbook. International Journal of New Trends in Arts, Sports \& Science Education, 2 (1), 8-26, 2013.

[8] Göçer, A. İlköğretim Türkçe ders kitaplarinin ölçme ve değerlendirme açisindan incelenmesi. Atatürk University Journal of Graduate School of Social Sciences, 11 (1), 197-210, 2008.

[9] Bakar, E., Keleş, Ö. \& Koçakoğlu, M. Evaluation of the teachers' views about grade 6th science and technology text

book set. Ahi Evran Üniversitesi Kırşehir Eğitim Fakültesi Dergisi, 10 (1), 41-50 2009.

[10] Yıldırım, A. \& Şimşek, H. Qualitative Research Methods in Social Sciences. Ankara: Seçkin Yayıncılık, 2011.

[11] MEB. (2017). Science Textbooks. MEB, 2017.

[12] MEB. Science Course Curriculum. MEB, 2018a

[13] Güzel, H. \& Adıbelli, S. Analysis of 9th grade physics textbook from an educational, visual and language perspective. Selçuk University, The Journal of Institute of Social Sciences, 26, 201-216, 2011.

[14] MEB. Turkish Course Curriculum. MEB, 2018b.

[15] Kavak, N. Tufan, Y. \& Demirelli, H. Science and technology literacy and informal science education: potential role of newspapers. Gazi University, Journal of Gazi Educational Faculty, 26 (3), 17-28, 2006.

[16] Wright, P. The comprehension of tabulated information: some similarities between reading prose and reading tables. International Society for Performance Improvement, 19 (8), 25-29, 1980.

[17] Raloff, J. (2001). Errant texts: Why some schools may not want to go by the book. Science News, 159 (11), 168-170, 2001.

[18] Şahin, M. The evaluation of textbooks in terms of message design principles. Ahi Evran Üniversitesi Kırşehir Eğitim Fakültesi Dergisi, 13 (3), 129-154, 2012.

[19] Şimşek, H. The teacher opinions for the fourth grade physic textbook in high schools. Unpublished Master Dissertation, Selçuk University, Institute of Educational Sciences, Konya, 2010.

[20] Iding, M. K. Can strategies facilitate learning from illustrated science texts books? International Journal of Instructional Media, 27 (3), 289-301, 2000. 